Lin, W.C. 1984. The effect of soil cooling and high intensity lighting on flowering of Alstroemeria 'Regina'. HortScience 19(4):515-516.

Powell, M.C. and A.C. Bunt. 1986. The effects of propagation date on flower production in $\mathrm{Al}$ stroemeria 'Campfire' and 'Red Sunset'. Scientia Hort. 28:147-157.

Vonk Noordegraaf, C. 1975a. Alstroemeria: Belichting bij 'Orchid', p. 15. In: Bloemisterij on- derzoek in Nederland, Aalsmeer, The Netherlands.

Vonk Noordegraaf, C. 1975b. Temperature and daylength requirements of Alstroemeria. Acts Hort. 51:267-274.

Vonk Noordegraaf, C. 1981. Bloemproduktie bij Alstroemeria 'Walter Fleming'. PhD Diss., Agr. Univ., Wageningen, The Netherlands.
Wilkins, H. F. W.E. Healy, and T.L. GilbertsonFerriss. 1980. Comparing and contrasting the control of flowering in Alstroemeria 'Regina', Freesia $\times$ hybrids and Lilium longiflorum, $\mathrm{p}$. 51-63. In: C. Brickell, D.F. Cutter, and M. Gregord (eds.). Petaloid monocotyledous, horticultural and botanical research. Academic, New York.

\title{
Temperature Requirements for Seed Germination of Three Penstemon Species'
}

\author{
Phil S. Allen' and Susan E. Meyer \\ Utah Division of Wildlife Resources, USDA Forest Service Intermountain \\ Research Station, Shrub Sciences Laboratory, 735 N. 500 East, Provo, \\ UT 84606
}

Additional index words. Penstemon eatonii, Penstemon palmeri, Penstemon strictus, perennials, seed dormancy, stratification, wildflowers

Abstract. To determine optimum germination temperatures and effective dormancybreaking procedures, field-grown (1983-85) seeds of 'Bandera' Rocky Mountain penstemon (Penstemon strictus Benth), 'Cedar' Palmer penstemon (Penstemon palmeri Gray), and firecracker penstemon (Penstemon eatonii Gray) were subjected to various cold stratification and incubation temperature treatments. Increased germination following an 8-week stratification occurred in seed lots containing dormant seeds, but a 2-week stratification generally failed to break dormancy. Older (1983) seeds of 'Bandera' and 'Cedar' penstemon germinated to full viability without stratification. All species showed a marked decrease in germination percentage above $20 \mathrm{C}$; $15 \mathrm{C}$ consistently produced maximum germination after 4 weeks. At $15 \mathrm{C}$, mean times to $90 \%$ of total germination were 11, 22, and 29 days for 'Bandera', 'Cedar', and firecracker penstemon, respectively. Transfer of seeds failing to germinate at warm temperatures ( 25 and $30 \mathrm{C})$ to $15 \mathrm{C}$ and applying $720 \mu \mathrm{M}$ gibberellic acid $\left(\mathrm{GA}_{3}\right)$ solution was effective in breaking primary dormancy of firecracker penstemon and secondary dormancy of 'Bandera' penstemon. Our findings suggest that incubation below 20C, combined with 8 weeks of stratification or the use of after-ripened seed, may improve seed propagation efforts for these species.

Widespread interest in perennials and in wildflowers for use as low-maintenance ornamental has increased marketing opportunities for native plants (Aimone, 1986; Allen, 1985; Cox and Klett, 1984; Gilbert, 1987; Otteson, 1986). Unfortunately, seed dormancy resulting in poor or sporadic germination can discourage growers from supplying desirable plant materials to the public (Aimone, 1986). For such species, information on germination requirements, seed age

Received for publication 7 Mar. 1989. This research was supported in part by Pittman-Robertson Federal Aid to Wildlife Project W82-R and by funds provided by the Utah Dept. of Agriculture. The cost of publishing this paper was defrayed in part by the payment of page charges. Under postal regulations, this paper therefore must be hereby marked advertisement solely to indicate this fact.

'Current address: Dept. of Horticultural Science, Univ. of Minnesota, St. Paul, MN 55108. effects on viability and dormancy, and effective dormancy-breaking procedures would benefit seed propagation efforts.

Penstemon spp. offer considerable potential for increased horticultural use. There are more than 250 perennial species of native North American penstemons (Cronquist et al., 1984), a few of which are currently cultivated (Kelaidis, 1986). While seed dormancy occurs in this genus, few reports on germination have been published (Atwater, 1980; Cox and Klett, 1984; Maguire and Overland, 1959; Salac and Hesse, 1975; Salac and Traeger, 1982).

In this study, we compared laboratory germination characteristics for successive yearly harvests of three penstemon species recently brought into field cultivation for seed production: 'Bandera' Rocky Mountain penstemon (Hooks and Oaks, 1982), 'Cedar' Palmer penstemon (Stevens and Monsen, 1988), and firecracker penstemon. In particular, the effects of cold stratification and of incubation temperature on laboratory germination rate and percentage were investigated.

Eight seed lots were obtained from producers during Sept. -Nov. 1985 (Table 1) and stored in paper containers in the laboratory $(\approx 22 \mathrm{C})$. Seeds had been held in warehouse storage by producers. The experiments described were conducted between Jan. and June 1986.

Viability for each seed lot was determined using tetrazolium staining (Grabe, 1970; Kitchen, 1988). Two 50-seed replications were imbibed on moist blotters for $12 \mathrm{hr}$, pierced with a needle, and immersed in a $1 \%$ $(\mathrm{w} / \mathrm{v})$ solution of buffered tetrazolium chloride. After $48 \mathrm{hr}$, seeds were bisected longitudinally and examined under a dissecting microscope. Seeds with embryos stained completely red were classed as viable; remaining seeds were classed as nonviable.

Two germination experiments were conducted. Treatments consisted of four replications of 50 seeds each, incubated on two

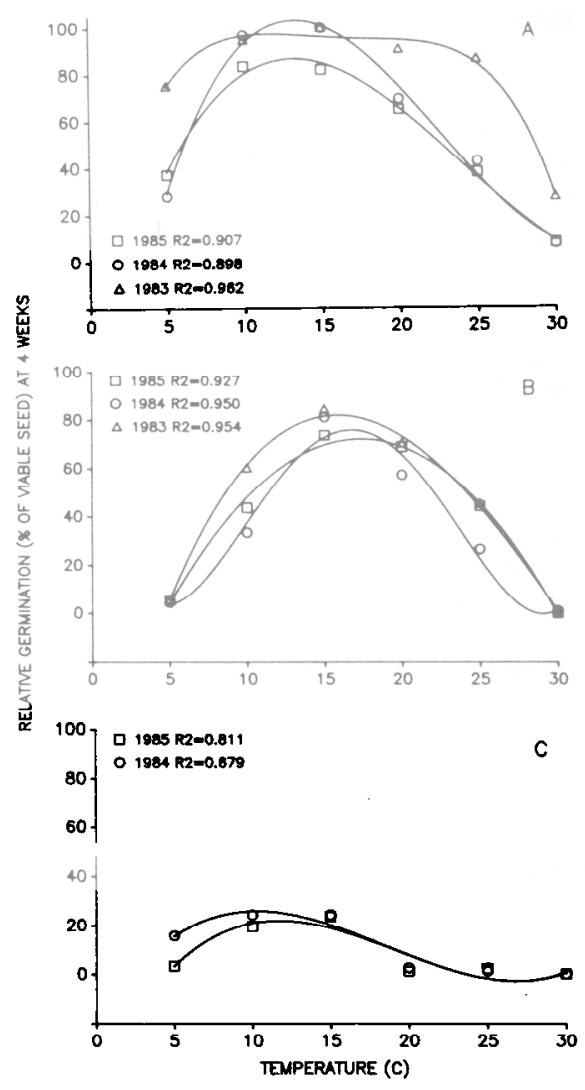

Fig. 1. Effect of temperature on seed germination of (A) 'Bandera', (B) 'Cedar', and (C) firecracker penstemon. Curves represent fitted polynomial equations $(P<0.001)$ for each seedlot. 
Table 1. Source data for experimental seedlots oPenstemon

\begin{tabular}{|c|c|c|c|}
\hline $\begin{array}{c}\text { Common and Latin } \\
\text { names }\end{array}$ & $\begin{array}{l}\text { Location } \\
\text { grown }\end{array}$ & $\begin{array}{l}\text { Production } \\
\text { years }\end{array}$ & $\begin{array}{c}\text { Seed class and } \\
\text { source }\end{array}$ \\
\hline $\begin{array}{l}\text { 'Bandera' Rocky } \\
\text { Mountain penstemon, } \\
\text { Penstemon strictus }\end{array}$ & Meeker, Colo. & $1983-85$ & $\begin{array}{l}\text { Foundation seed; } \\
\text { Upper Colorado } \\
\text { Environmental Plant } \\
\text { Materials Center } \\
(\mathrm{SCS})^{z} \text {, Meeker, Colo. }\end{array}$ \\
\hline $\begin{array}{l}\text { 'Cedar' Palmer } \\
\text { penstemon, } \\
\text { Penstemon palmeri }\end{array}$ & Ephraim, Utah & $1983-85$ & $\begin{array}{l}\text { Foundation seed; } \\
\text { Great Basin } \\
\text { Experimental Station } \\
(\text { USFS) })^{y} \text {, Ephraim, Utah }\end{array}$ \\
\hline $\begin{array}{l}\text { Firecracker } \\
\text { penstemon, } \\
\text { Penstemon eatonii }\end{array}$ & Caldwell, Idaho & $1984-85$ & $\begin{array}{l}\text { Commercial seedlots; } \\
\text { Native Plants, Inc., } \\
\text { Salt Lake City, Utah }\end{array}$ \\
\hline
\end{tabular}

${ }^{2}$ Soil Conservation Service.

U. S. Forest Service.

Table 2. Absolute percent germination of Penstemon seeds after stratification (5C) for 0,2 , or 8 weeks followed by incubation (15C) for 10,8 , or 2 weeks, respectively.

\begin{tabular}{|c|c|c|c|c|c|}
\hline \multirow{2}{*}{$\begin{array}{c}\text { Type of } \\
\text { penstemon }\end{array}$} & \multirow[b]{2}{*}{ Year } & \multirow{2}{*}{$\begin{array}{c}\text { Viability } \\
(\%)^{y}\end{array}$} & \multicolumn{3}{|c|}{ Stratification (weeks) } \\
\hline & & & 0 & 2 & 8 \\
\hline \multirow{4}{*}{ Bandera } & & & \multicolumn{3}{|c|}{ Germination (\%) } \\
\hline & 1983 & 95 & 92 & 93 & 90 \\
\hline & 1984 & 93 & $79 *$ & 93 & 98 \\
\hline & 1985 & 94 & $50^{* *}$ & $68 * *$ & $82 *$ \\
\hline \multirow[t]{2}{*}{ Cedar } & 1983 & 78 & 76 & $54 * *$ & 83 \\
\hline & 1984 & 88 & $68 * *$ & $74 *$ & 84 \\
\hline \multirow{3}{*}{ Firecracker } & 1985 & 63 & 56 & 58 & 56 \\
\hline & 1984 & 76 & $24 * *$ & $15^{* *}$ & 65 \\
\hline & 1985 & 87 & $24 * *$ & & $46^{* *}$ \\
\hline
\end{tabular}

${ }^{2}$ Values within rows significantly different from viability control at $P=0.05(*)$ and $0.01\left({ }^{* *}\right)$.

"Viability determined by tetrazolium staining; see text for details.

layers of germination blotting paper in covered petri dishes and moistened as needed. Dishes were placed in random arrangement in dark germinators. Germinated seeds (radicle emerged to $1 \mathrm{~mm}$ ) were counted and removed under cool-white fluorescent lights at least weekly. Light was probably neither strongly limiting nor inhibiting under these conditions (S. E. M., unpublished data).

In the first experiment, seeds were subjected to three cold-stratification treatments: $15 \mathrm{C}$ for 10 weeks (no stratification), $5 \mathrm{C}$ for 2 weeks followed by $15 \mathrm{C}$ for 8 weeks (2week stratification), and $5 \mathrm{C}$ for 8 weeks followed by $15 \mathrm{C}$ for 2 weeks ( 8 -week stratific a $\mathrm{t}$ i o n ).

In the second experiment, seeds were incubated at a constant $5,10,15,20,25$, or $30 \mathrm{C}$ for 4 weeks. At the end of 4 weeks, ungerminated seeds from the $25 \mathrm{C}$ and $30 \mathrm{C}$ treatments (warm temperatures) were transferred to $15 \mathrm{C}$ on blotters moistened either with water of $720 \mu \mathrm{M}$ gibberellic acid $\left(\mathrm{GA}_{3}\right)$ solution. Ungerminated seeds in the $15 \mathrm{C}$ treatments were left in the initial test conditions to serve as controls.

All germination and viability data were arcsin-transformed before analysis of variance to decrease variance heterogeneity associated with binomial data (Little and Hills, 1978, p. 159); original data are reported. Dunnet's test for comparing treatment means with controls was used where appropriate. Absolute germination percentages were used for analysis of the first experiment, with tet- razolium viability included as a measure of maximum possible germination for comparative purposes. For the second experiment, germination data were converted to a relative (percent of viable seed) basis to facilitate comparisons among seed lots. Temperature response curves were determined for each seed lot using polynomial regression techniques. Time to $90 \%$ of total germination $\left(\mathrm{T}_{90}\right)$ at the optimum temperature (i.e., temperature resulting in maximum 4-week germination) was determined for each seed lot by interpolating on plotted rate curves.

'Bandera' harvested in 1983 germinated to full viability without stratification (Table 2). Seed harvested in 1984 and 1985 responded favorably to stratification treatments, although the 1985 seedlots failed to germinate to full viability even with an 8-week stratification.

Stratification enhanced germination of 'Cedar' only for 1984 seeds (Table 2). Seeds harvested in 1985 had low viability, were not dormant, and showed no response to stratification. Nondormant 1983 seeds showed depressed germination following a 2-week stratification, but germinated to full viability with the 8-week stratification treatment. Reduced germination following exposure to low temperature has been described as a type of secondary dormancy (Baskin and Baskin, 1985; Bewley and Black, 1982, p. 308). Kitchen (1988) has reported this phenomenon in other seedlots of this species and in several other penstemons.
Most firecracker penstemon seeds were dormant for both harvest years (Table 2). While 8 weeks of stratification broke dormancy in the 1984 seed lot, nearly half of the 1985 seeds were still dormant following this treatment.

All species and all seed lots germinated maximally after 4 weeks at $15 \mathrm{C}$ (Fig. 1). In general, germination was drastically reduced at higher temperatures. Reduced 4-week germination at 5 and $10 \mathrm{C}$ is due to a slower germination rate at low temperatures. After 8 weeks, germination at 5 and $10 \mathrm{C}$ was equivalent to that in the $15 \mathrm{C}$ treatment (data not shown).

Of the three species, 'Bandera' had the highest relative germination at all temperatures (Fig. 1A). Temperature sensitivity, as indicated by reduced germination at temperatures above and below the optimum, appears to be related to the degree of seed dormancy. The nondormant 1983 seed lot germinated well over a much wider range of temperatures than did the 1984 and 1985 seed lots, which contained dormant seeds.

Germination of 'Cedar' was highly temperature-sensitive and was completely prevented at 30C (Fig. 1B). Relative germination of the 1984 seed lot (containing dormant seeds) was generally lower than for the other two lots, particularly at 10 and $25 \mathrm{C}$. This result suggests that temperature sensitivity increases with increased seed dormancy in this species as well.

Firecracker penstemon seeds did not germinate above 15C (Fig. 1C). Seeds harvested in 1984 germinated more rapidly at lower temperatures than did 1985 seeds (data not shown), although neither seedlot had germination percentages that approached tetrazolium viability estimates.

Poor germination at 25 and $30 \mathrm{C}$ prompted efforts to determine whether ungerminated seeds remained viable following exposure to supraoptimal temperatures for 4 weeks (as indicated by germination following transfer to $15 \mathrm{C}$ and moistening with either water or GA solution). For 'Bandera', a 4-week incubation at supraoptimal temperatures resulted in a $20 \%$ decrease in total germination following transfer to $15 \mathrm{C}$ and moistening with water only (Table 3). However, when moistened with the $\mathrm{GA}_{3}$ solution, germination percentage was not significantly different from the control. This change suggests that exposure to high temperatures during imbibition can induce secondary dormancy, i.e., "thermodormancy" (Bewley and Black, 1982 , p. 328), which can be overcome by application of $\mathrm{GA}_{3}$ in this species.

In contrast to 'Bandera', seeds of 'Cedar' and firecracker penstemon exposed to high temperatures showed no reduction in total germination following removal to $15 \mathrm{C}$. Apparently, failure of these seeds to germinate at high temperatures was due only to enforced, or relative, dormancy (Bewley and Black, 1982, p. 63). Of interest is the marked increase in germination percentage of firecracker penstemon following application of $\mathrm{GA}_{3}(60 \%$. as compared with $22 \%$ in the control). Evidently, primary dormancy of fire- 
Table 3. Relative percent germination of Penstemon seeds incubated at 15, 25, or 30C for 4 weeks, followed by incubation at $15 \mathrm{C}$ for 1 week. During the 5 th week, seeds were moistened with water or $720 \mu \mathrm{M} \mathrm{GA}_{3}$ solution.

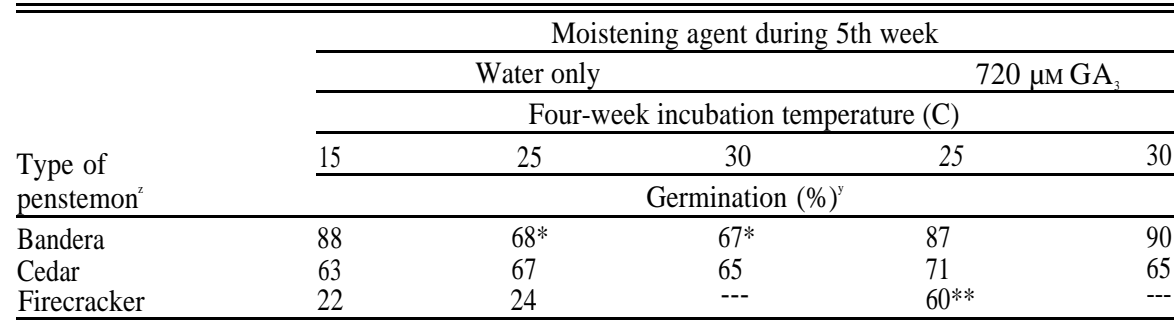

${ }^{2}$ For each type of penstemon, values are averaged across years of collection.

$*$,**Values within rows significantly different from $15 \mathrm{C}$ control at $P=0.05$ and 0.01 , respectively.

cracker penstemon seeds was largely broken by return to $15 \mathrm{C}$ and moistening with $\mathrm{GA}_{3}$ solution.

As determined by interpolation from plotted rate curves (not shown), mean $\mathrm{T}_{90}$ values at $15 \mathrm{C}$ were 11,22 , and 29 days for 'Bandera', 'Cedar', and firecracker penstemon, respectively. Poor germination (low percentage and slow rate) of firecracker penstemon increases the difficulty of seed propagation. For this species; use of 1-yearold seed did not preclude the need for stratification, and, even with stratification, germination remained sporadic. Treatment with $\mathrm{GA}_{3}$ solution may be an effective means of breaking dormancy in this species. However, further research to develop suitable techniques is needed, as we have noted that seedlings resulting from $\mathrm{GA}_{3}$-treated seeds were spindly and difficult to maintain under greenhouse conditions.

In the field, penstemons are typically seeded in the fall (Hooks and Oaks, 1982; Plummer et al., 1968; Salac and Traeger, 1982: Stevens and Monsen, 1988). Presumably, the winter environment naturally provides cold stratification. Artificial stratification may be necessary for seed propagation under greenhouse conditions. In this study, no germination occurred during 2 weeks of stratification. However, between $50 \%$ and $100 \%$ germination in the 8 -week stratification treatments occurred during stratification. Thus, stratification treatments are not perceived as an effective means of obtaining more uniform germination.

An alternative to stratification for 'Bandera' and 'Cedar' penstemons is to use "afterripened" seed (seed that has lost dormancy during dry storage). For both of these penstemons, seed harvested in $1983\left(\approx 2 \frac{1}{2} 2\right.$ years before being used in this study) had lost all dormancy. Stevens et al. (1981) have reported high viability for both of these species following several years of warehouse storage.

Based on the above results, 'Bandera' and 'Cedar' appear relatively easy to germinate as long as suitable temperatures are provided. Firecracker penstemon presents more difficulty because of primary dormancy that is not substantially reduced during storage. Results of experiments with wild-collected seed (Kitchen, 1988) suggest that it maybe possible to select a firecracker penstemon cultivar with lower seed dormancy, thereby improving seed propagation.

\section{Literature Cited}

Aimone, T. 1986. Success with perennials. GrowerTalks 49(11):125-133.

Allen, P.S. 1985. Studies on seed performance of five arid landscape species. MS Thesis, Brigham Young Univ., Provo, Utah.

Atwater, B.R. 1980. Germination, dormancy, and morphology of seeds of herbaceous ornamental plants. Seed Sci. \& Technol. 8:523-573.

Baskin, J. M. and C. C. Baskin. 1985. The annual dormancy cycle in buried weed seeds: A con- tinuum. Bioscience 35(8):492-498.

Bewley, J.D. and M. Black. 1982. Physiology and biochemistry of seeds in relation to germination: 11. Viability, dormancy, and environmental control. Springer-Verlag, Berlin.

Cox, R.A. and J.E. Klett. 1984. Seed germination requirements of native Colorado plants for use in the landscape. Plant Prop. 30(2):6-10.

Cronquist, A., A.H. Holmgren, N.H. Holmgren, J.L. Reveal, and P.K. Holmgren. 1984. Intermountain flora. vol. 4. New York Botanical Garden, Bronx.

Gilbert, B. 1987. In from the fields, wildflowers find anew welcome among gardeners. Smithsonian 18(1):37-45.

Grabe, D.F. (cd.). 1970. Tetrazolium testing handbook for agricultural seeds. Handbook on Seed Testing. Contrib. 29. Assn. Offic. Seed Anal.

Hooks, R.F. and W.R. Oaks. 1982. 'Bandera' Rocky Mountain penstemon. HortScience 17:683.

Kelaidis, P. 1986. Penstemons. Pacific Hort. 48(2):28-34.

Kitchen, S.G. 1988. Germination studies with fifteen species of Intermountain penstemons. MS Thesis, Brigham Young Univ., Provo, Utah.

Little, T.M. and F.J. Hills. 1983. Agricultural experimentation: Design and analysis. Wiley, New York.

Maguire, J.D. and A. Overland. 1959. Laboratory germination of seeds of woody and native plants. Wash. Agr. Expt. Sta. Circ. 349.

Otteson, C. 1986. Landscape perennials are transformed by changing seasons. Amer. Nurseryman 163(8):72-75.

Plummer, A. P., D.R. Christensen, and S.B. Monsen. 1968. Restoring big game range in Utah. Utah State Dept. Fish and Game Publ. 68-3

Salac, S.S. and M.C. Hesse. 1975. Effects of storage and germination conditions on the germination of four species of wildflowers. J. Amer. Soc. Hort. Sci. 100:359-361.

Salac, S.S.and J. M. Traeger. 1982. Seeding dates and field establishment of wildflowers. HortScience 17:805-806

Stevens, R., K.R. Jorgensen, and J.N. Davis. 1981. Viability of seed from 32 shrub and forb species through 15 years of warehouse storage. Great Basin Naturalist 41:274-278.

Stevens, R. and S.B. Monsen. 1988. 'Cedar' Palmer penstemon: A selected penstemon for semiarid ranges. Rangelands 10:163-164. 